\title{
The Rescue Episode of First Sighted Juveniles of Brown-fish owl ( Bubo zeylonensis) in Bastar, Chhattisgarh, India
}

\section{Panchratan Singh Negi ${ }^{1 *}$, Ravi Naidu ${ }^{2}$}

'Veterinary Hospital, Bastar, Jagdalpur, 494001 Chhattisgarh ${ }^{2}$ Conservation \& Research of Wilderness foundation, Jagdalpur, 4940o1, Chhattisgarh, India

\section{Introduction:}

The avifaunal diversity of Bastar District is very rich. Our previous studies had revealed that there is a presence of 325 species (Chandra et al., 2015; Dutta, 2017). This includes resident as well as migratory birds. Amongst the Owls and owlets, most of the species are resident like Spotted owlet, Jungle Owlet, Wood owl, Scops owl, Indian Eagle-owl. However, the sighting of Brown-fish owl is very rare. The First author is frequently observing this Brown fish owl since 2014 in early summer at adjacent to a nallah (Ganesh Bahar ). The Brown-fish owl is a fish owl species in the family known as Strigidae. The distribution of Brown Fishowl (Bubo zeylonensis) is restricted towards the south of the Himalaya to Sri Lanka, Middle East, China, and Southeast Asia. This species is listed as least concern, but the population is gradually declining due to habitat loss (BirdLife International, 2015). Its habitat consists of deciduous, semi-deciduous, open evergreen forests, wellwooded lowlands, and sacred groves, mostly in lowlands (Ali \& Ripley, 1987) It's prominent identifying characteristics are the prominent ear tufts and upperparts are rufous-brown and heavily streaked. Its Underparts are pale fulvous with fine, pale brown to rufous cross-bars, bold black shaft-streaks, and finer brown barring. Eyes are golden yellow. The bill is pale greenish-grey, and dusky on the upper ridge and tip. Its featherless feet are yellow. Body size, it ranges from 48 to $61 \mathrm{~cm}$, its weight ranging from 1.1 to $2.5 \mathrm{~kg}(2.4$ to $5.5 \mathrm{lb})$. Females are often larger and heavier than males (Grimmett et al., 1999). Brown-fish owls feed mainly on fish, frogs, and crabs, but will also take rodents, birds, reptiles and large beetles.

The breeding season is generally from November to March. The Brown-fish owl can breed in a variety of habitats including sacred groves, and to nest in old trees like mango and other large trees.

\section{Ourobservation:}

Our frequent tracking for bird watching starts from 6 o'clock in the morning to 4 o'clock evening during which we cover almost 4 to 5 kilometer area of Ganesh Bahar Nala. Our earlier tracking already documented more than 100
Study Area: Bastar,Chhattisgarh, India

Coordinated: - 19.0257" N; 82.1644"E

Keywords: Avifaunal diversity,

species from this area only. Brown-fish-owls were seen in the study area for the last 6 years, but we never noticed the nest and juveniles of this species. Thus, we were not sure about its residential status (migratory or resident). O n 15 March 2020, we started tracking for bird watching from 6 o'clock in the morning from the Kurandi jungle towards Ganesh Bahar nala. At about 12 o'clock suddenly heard a loud human's calls from East to Ganesh Bahar nallah inside the jungle. Within no time reached the spot, where we found 4 minor boys with one young man, putting two Brown-f ish owls juveniles, wrapping in cloth (towel) to take them to their house. Immediately rescued them by saying them that these are the ornaments of jungles. After a little persuasion, they agreed to leave both juvenile owls to their nest in an old tree nearby (Plate-2). We both the authors spent a little bit of time there to ensure their safety. We observed both of the parent owls flying nearby trees, making the sound from their beak to scare us, to get away us from the site. We maintained some distance from the spot and planned to protect them from the villagers. We kept watching on both the juveniles till their feathers grew up and they started flying. Till 23 March 2020, we found both of them were not there in the nest we didn't trace their parents also in that vicinity then.

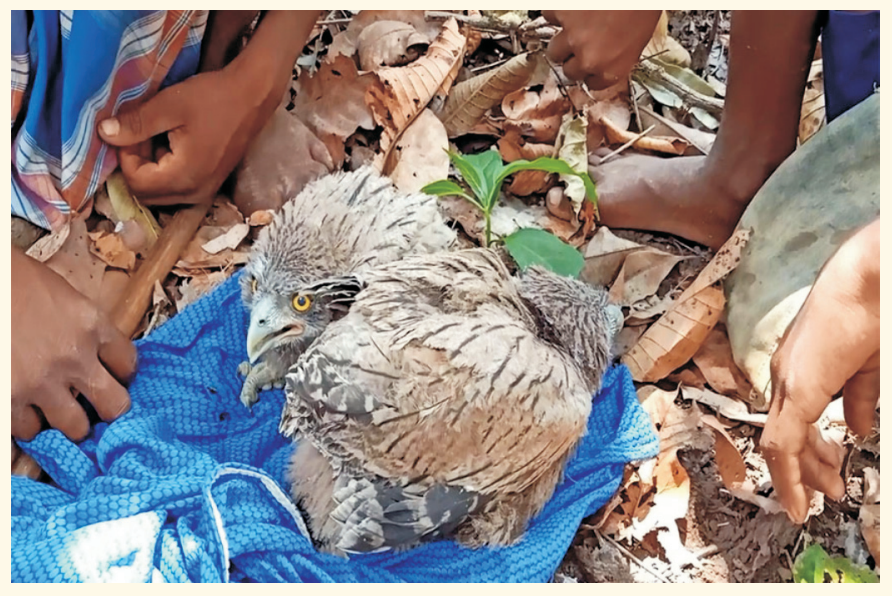

Plate-1: Two rescued juveniles of Brown-fish owl 


\section{NOTES ON NATURAL HISTORY}

\section{Conclusion:}

Marks et al. (1999) stated that owls like Brown-fish owl reuse the same next site again and again. Ali and Ripley (1987) also reported that the breeding season of Brown-fish owl starts from November to March, but as late as April in Sri Lanka. Our observation for the breeding season of this bird also supports the same period. The present observation may act as a piece of baseline information for further breeding studies of owls in the Bastar division..

Acknowledgements:

We express sincere gratitude to Dr. Sushil Kumar Dutta, Department of Zoology, Govt. PG College, Jagdalpur, Chhattisgarh, India for his constructive guidance. My heartful acknowledgments are due to Rajendra Prasad Gupta for his continuous encouragement.

\section{References:}

Ali,S.\& Ripley,S.D.(1968-74): Handbook of the Birds of India \& Pakistan (1oVols.). Pub. by: Oxford University Press, UK.

Dutta, S.K.,(2017): Avifaunal diversity and conservation status in Bastar district of Chhattisgarh, India: an update. Ambient Sci., 04(2):31-33.

Grimmett, R., Inskipp, C., \& Inskipp, T. (1999): Birds of India, Pakistan, Nepal, Bangladesh, Bhutan, Sri Lanka, and the Maldives. Pub. by: Princeton: Princeton University Press. Delhi. 384 P.

Kazmierczak, K. (200o): A field guide to the birds of India, Sri Lanka, Nepal, Bhutan, Bangladesh, and the Maldives. Pub. by: Om Book Service, India. 352 P.

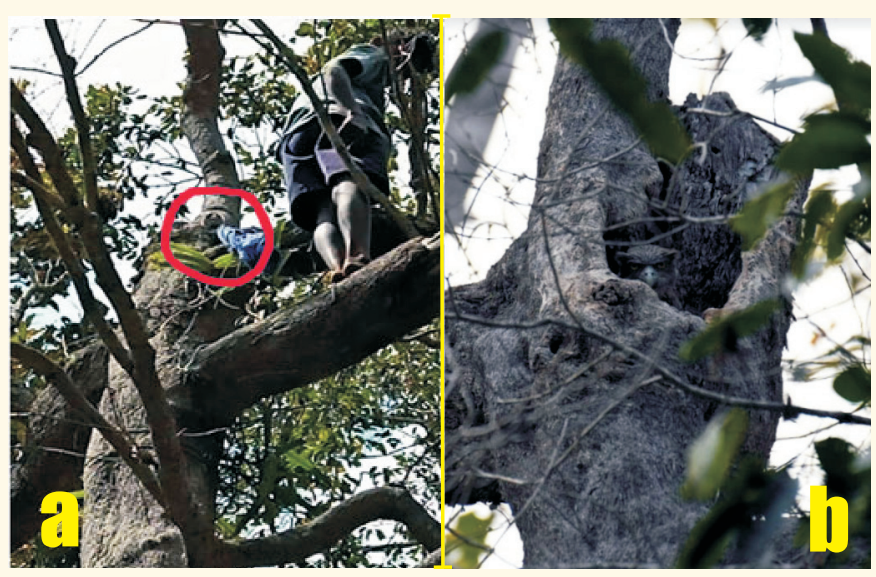

Plate-2: a) Miner tribal boy putting juveniles back to their nest b) Juveniles again in their nest.

Marks, J.S., Cannings, R.J. \& Mikkola, H. (1999): Family Strigidae (Typical Owls), pp. 76-242. In: del Hoyo, J., A. Elliot \& J. Sargatal (Eds): Handbook of the Birds of the World. Volume 5: Barn-Owls.

BirdLife International (2015): Species factsheet: Ketupa zeylonensis. Downloaded from http://www.birdlife.org. Accessed on April 02, 2015. 